\title{
ANALISIS EFEKTIVITAS DAN KONTRIBUSI PAJAK BUMI DAN BANGUNAN PERDESAAN DAN PERKOTAAN (PBB-P2) SEBAGAI SUMBER PENDAPATAN ASLI DAERAH KABUPATEN MINAHASA, KABUPATEN MINAHASA UTARA, DAN KOTA MANADO
}

\author{
Juriko Chichi $^{1}$, Grace B. Nangoi ${ }^{2}$, Sonny Pangerapan ${ }^{3}$ \\ ${ }^{1,2,3}$ Fakultas Ekonomi dan Bisnis. Jurusan Akuntansi. Universitas Sam Ratulangi, J1. Kampus Bahu, Manado, \\ 95115, Indonesia. \\ E-mail : jurikochichi@gmail.com
}

\begin{abstract}
The collection of land and building tax is based on law no. 12 year 1985. Land and building tax for rural and urban district is a new potential income for own-source revenue. The purpose of this research is to find out the effectiveness and contribution of land and building tax for rural and urban district as a own-source revenue for Minahasa District, Northern Minahasa District, and Manado City. This research uses the qualitative descriptive method. Method that used for data collection in this research is direct interview with the parties appointed by the Local Revenue Office in each district. Result of the research shows that the effectiveness of land and building tax for rural and urban district for Northern Minahasa District is 103,26\% (very effective), Manado City is 95,52\% (effective), and Minahasa District is 69,78\% (less effective). The contributions of land and building tax for rural and urban district for own-source revenue for Northern Minahasa District is 17,27\% (less), Manado City is 9,46\% (very less), and Minahasa District is 5,29\% (very less).
\end{abstract}

Keyword: PBB-P2, income, effectiveness, contributions

\section{PENDAHULUAN}

Undang-Undang Nomor 28 Tahun 2009 sebagai pengganti Undang-Undang Nomor 18 Tahun 1997 dan Undang-Undang Nomor 34 Tahun 2000 tentang Pajak Daerah dan Retribusi Daerah dan berlaku aktif efektif mulai 1 Januari 2010. Latar belakang pembentukan Undang-Undang Nomor 28 Tahun 2009 yaitu untuk memberikan kewenangan yang lebih besar kepada daerah dalam mengatur Pajak Daerah dan Retribusi Daerah, meningkatkan akuntabilitas dalam penyediaan layanan dan pemerintahan, memperkuat otonomi daerah serta memberikan kepastian hukum bagi masyarakat dan dunia usaha. Sesuai dengan UndangUndang Nomor 28 Tahun 2009, jenis pajak yang dipungut oleh pemerintah daerah adalah Pajak Provinsi, meliputi; Pajak Kendaraan Bermotor, Bea Balik Nama Kendaraan Bermotor, Pajak Bahan Bakar Kendaraan Bermotor, Pajak Air Permukaan, Pajak Rokok, sedangkan Pajak Kabupaten/Kota, meliputi; Pajak Hotel, Pajak Restoran, Pajak Hiburan, Pajak Reklame, Pajak Penerangan Jalan, Pajak Mineral Bukan Logam dan Batuan, Pajak Parkir, Pajak Air Tanah, Pajak Sarang Burung Walet, Pajak Bumi dan Bangunan Perdesaan dan Perkotaan (PBB-P2), dan Bea Perolehan Hak Atas Tanah dan Bangunan.

Dasar hukum Pajak Bumi dan Bangunan adalah Undang-Undang No. 12 Tahun 1985 sebagaimana telah diubah dengan Undang-Undang No. 12 tahun 1994. PBB merupakan jenis Pajak Pusat tetapi hasil penerimaannya dibagikan kepada Daerah dan terbesar untuk Kabupaten/Kota. Pajak Bumi dan Bangunan merupakan pajak dengan sistem pemungutan Official Assessment System, dimana sistem ini pihak fiskus yakni Pemerintah Daerah harus lebih proaktif dalam melakukan perhitungan serta menetapkan pajak yang terutang dan mendistribusikannya (Patara, 2016).

Di dalam Undang-Undang Nomor 33 Tahun 2004 tentang Perimbangan Keuangan Antara Pemerintah Pusat dan Pemerintah Daerah disebutkan bahwa sumber Pendapatan 
Daerah terdiri dari Pendapatan Asli Daerah, Bagi Hasil Pajak, dan Bukan Pajak. Dengan berlakunya Undang-Undang Nomor 28 Tahun 2009, maka seluruh penerimaan dari PBB-P2 adalah hak daerah karena kegiatan proses pendataan, penilaian, penetapan, pengadministrasian, pemungutan/penagihan dan pelayanan PBB-P2 diselenggarakan sepenuhnya oleh Pemerintah Daerah. Tujuan dari penelitian ini adalah untuk menganalisis efektivitas dan kontribusi Pajak Bumi dan Bangunan Perdesaan dan Perkotaan Kabupaten Minahasa, Kabupaten Minahasa Utara, dan Kota Manado.

\section{TINJAUAN PUSTAKA}

\subsection{Konsep Akuntansi}

Akuntansi merupakan sistem informasi yang menyediakan laporan bagi para pihak pengambil keputusan (stakeholder) mengenai aktivitas ekonomi dan kondisi perusahaan. Di dalam penerapannya, akuntansi mengikuti prinsip-prinsip akuntansi yang berlaku secara umum, sehingga memungkinkan para stakeholder untuk membandingkan kinerja perusahaan dengan perusahaan lain yang sejenis (Lubis, 2015: 2). Akuntansi mengacu pada 3 (tiga) aktivitas dasar yaitu mengidentifikasi, merekam, dan mengkomunikasikan kejadian ekonomi yang terjadi pada organisasi untuk kepentingan pihak pengguna. Contoh pengguna internal adalah individu-individu di dalam perusahaan yang berkepentingan untuk merencanakan, mengoordinasikan, dan menjalankan kegiatan bisnis perusahaan, seperti manajer, supervisor, direktur, internal audit dan karyawan perusahaan.

\subsection{Konsep Pajak}

Definisi pajak menurut Undang-Undang Nomor 16 tahun 2009 tentang perubahan keempat atas Undang-Undang Nomor 6 tahun 1983 tentang Ketentuan Umum dan Tata Cara Perpajakan pada pasal 1 ayat 1 berbunyi pajak adalah kontribusi wajib kepada negara yang terutang oleh orang pribadi atau badan yang bersifat memaksa berdasarkan undang-undang, dengan tidak mendapatkan imbalan secara langsung dan digunakan untuk keperluan negara bagi sebesar-besarnya kemakmuran rakyat. Sedangkan menurut Prof. Dr. Rochmat Soemitro, S.H., pajak adalah iuran rakyat kepada kas Negara berdasarkan undang-undang (yang dapat dipaksakan) dengan tiada mendapat jasa timbal (kontraprestasi) yang langsung dapat ditunjukkan dan dapat digunakan untuk membayar pengeluaran umum.

\subsection{Sistem Pemungutan Pajak}

1. Official Assessment System

Adalah suatu sistem pemungutan yang memberi wewenang kepada Pemerintah (fiskus) untuk menentukan besarnya pajak yang terutang.

Ciri-ciri Official Assesment System:

a. Wewenang untuk menentukan besarnya pajak terutang berada pada fiskus

b. Wajib pajak bersifat pasif

c. Utang pajak timbul setelah dikeluarkan surat ketetapan pajak oleh fiskus.

2. Self Assessment System

Adalah suatu sistem pemungutan yang memberi wewenang, kepercayaan, tanggung jawab kepada wajib pajak untuk menghitung, memperhitungkan, membayar, dan melaporkan sendiri besarnya pajak yang harus dibayar.

3. Withholding System

Adalah suatu sistem pemungutan pajak yang memberi wewenang kepada pihak ketiga untuk memotong atau memungut besarnya pajak yang terutang oleh wajib pajak (Sumarsan, 2015: 14).

\subsection{Pendapatan Asli Daerah}

Pengertian Pendapatan Asli Daerah menurut Undang-Undang No. 28 Tahun 2009 yaitu sumber keuangan daerah yang digali dari wilayah daerah yang bersangkutan yang 
terdiri dari hasil pajak daerah, hasil retribusi daerah, hasil pengelolaan kekayaan daerah yang dipisahkan dan lain-lain Pendapatan Asli Daerah yang sah.

Adapun sumber-sumber Pendapatan Asli Daerah menurut Undang-Undang Republik Indonesia Nomor 32 Tahun 2004, yaitu:

1. Pendapatan Asli Daerah (PAD) yang terdiri dari:

a. Hasil Pajak Daerah yaitu pungutan daerah menurut peraturan yang ditetapkan oleh daerah untuk pembiayaan rumah tangganya sebagai badan hukum publik. Pajak daerah sebagai pungutan yang dilakukan pemerintah daerah yang hasilnya digunakan untuk pengeluaran umum yang balas jasanya tidak langsung diberikan sedang pelaksanaannya bisa dapat dipaksakan.

b. Hasil Retribusi Daerah, yaitu pungutan yang telah secara sah menjadi pungutan daerah sebagai pembayaran pemakaian atau karena memperoleh jasa atau arena memperoleh jasa pekerjaan, usaha atau milik pemerintah daerah bersangkutan. Retribusi daerah mempunyai sifat-sifat yaitu pelaksanaannya bersifat ekonomis, ada imbalan langsung walau harus memenuhi persyaratanpersyaratan formil dan materil, tetapi ada alternatif untuk mau tidak membayar, merupakan pungutan yang sifatnya budgetairnya tidak menonjol, dalam hal-hal tertentu retribusi daerah adalah pengembalian biaya yang telah dikeluarkan oleh pemerintah daerah untuk memenuhi permintaan anggota masyarakat.

c. Hasil perusahaan milik daerah dan hasil pengelolaan kekayaan daerah yang dipisahkan. Hasil perusahaan milik daerah merupakan pendapatan daerah dari keuntungan bersih perusahaan daerah yang berupa dana pembangunan daerah dan bagian untuk anggaran belanja yang disetor ke kas daerah, baik perusahaan daerah yang dipisahkan, sesuai dengan motif pendirian dan pengelolaan, maka sifat perusahaan daerah adalah suatu kesatuan produksi yang bersifat menambah pendapatan daerah, memberi jasa, menyelenggarakan kemanfaatan umum, dan memperkembangkan perekonomian daerah.

d. Lain-lain Pendapatan Daerah yang sah ialah pendapatan-pendapatan yang tidak termasuk dalam jenis-jenis pajak daerah, retribusi daerah, pendapatan dinas-dinas. Lain-lain usaha daerah yang sah mempunyai sifat yang pembuka bagi pemerintah daerah untuk melakukan kegiatan yang menghasilkan baik berupa materi dalam kegiatan tersebut bertujuan untuk menunjang, melapangkan, atau memantapkan suatu kebijakan daerah disuatu bidang tertentu.

2. Dana Perimbangan diperoleh melalui bagian pendapatan daerah dari penerimaan Pajak Bumi dan Bangunan Pertambangan sumber daya alam dan serta Bea Perolehan Hak atas Tanah dan Bangunan. Dana perimbangan terdiri atas dana bagi hasil, dana alokasi umum, dan dana alokasi khusus.

3. Lain-lain Pendapatan Daerah yang sah adalah pendapatan daerah dari sumber lain misalnya sumbangan pihak ketiga kepada daerah yang dilaksanakan sesuai dengan peraturan perundang-undangan yang berlaku.

\subsection{Pajak Bumi dan Bangunan Perdesaan dan Perkotaan (PBB-P2)}

Pajak Bumi dan Bangunan, sektor Perkotaan dan Perdesaan dikelola oleh Pemerintah Daerah paling lambat 31 Desember 2013, hal ini sesuai dengan UU. No 28 Tahun 2009 tentang Pajak Daerah dan Retribusi Daerah. Pajak Bumi dan Bangunan (PBB) Perdesaan dan Perkotaan adalah pajak atas bumi dan bangunan yang dimiliki, dikuasai, dan atau dimanfaatkan oleh pribadi atau badan, kecuali kawasan yang digunakan untuk kegiatan usaha, perkebunan, perhutanan, dan pertambangan. 


\subsection{Dasar Hukum Pemungutan PBB-P2}

Pemungutan PBB Perdesaan dan Perkotaan di Indonesia saat ini didasarkan pada dasar hukum yang jelas dan kuat, sehingga harus dipatuhi oleh masyarakat dan pihak yang terkait. Dasar hukum pemungutan PBB Perdesaaan dan Perkotaan pada suatu Kabupaten/Kota adalah sebagaimana di bawah ini.

1. Undang-Undang Nomor 28 Tahun 2009 tentang Pajak Daerah dan Retribusi Daerah

2. Peraturan Daerah Kabupaten/Kota yang mengatur tentang PBB Perdesaan dan Perkotaan

3. Keputusan Bupati/Walikota yang mengatur tentang PBB Perdesaan dan Perkotaan sebagai aturan pelaksanaan Peraturan Daerah tentang PBB Perdesaan dan Perkotaan pada Kabupaten/Kota dimaksud.

\subsection{Asas Pajak Bumi dan Bangunan}

1. Sederhana

Undang-Undang No. 12 Tahun 1985 tentang Pajak Bumi dan Bangunan merupakan penyederhanaan dari bermacam-macam jenis atau pungutan pajak yang pernah diberlakukan di Indonesia.

2. Adil

Adil dalam Pajak Bumi dan Bangunan dimaksudkan lebih kepada objek.

3. Kepastian dalam Hukum

Dengan diundangkannya Pajak Bumi dan Bangunan maka akan mempunyai kekuatan dan kepastian hukum yang merupakan pedoman bagi masyarakat untuk tidak raguragu melaksanakan kewajibannya.

4. Gotong Royong

Asas ini lebih tercermin pada semangat keikutsertaan masyarakat dalam mendukung pelaksanaan undang-undang Pajak Bumi dan Bangunan (Samudra, 2015: 263).

\subsection{Tujuan Pengalihan PBB-P2}

Tujuan pengalihan PBB-P2 menjadi pajak daerah sesuai undang-undang Pajak Daerah dan Retribusi Daerah (PDRD) ialah sebagai berikut.

1. Meningkatkan akuntabilitas penyelenggaraan otonomi daerah.

2. Memberikan peluang baru kepada daerah untuk mengenakan pungutan baru (menambah jenis pajak daerah dan retribusi daerah).

3. Memberikan kewenangan yang lebih besar dalam perpajakan dan retribusi dengan memperluas basis pajak daerah.

4. Memberikan kewenangan kepada daerah dalam penetapan tarif pajak daerah.

5. Menyerahkan fungsi pajak sebagai instrumen penganggaran dan pengaturan pada daerah.

\subsection{Efektivitas}

Efektivitas adalah suatu ukuran keberhasilan atau kegagalan dari organisasi dalam mencapai suatu tujuan. Efektivitas PBB-P2 adalah nilai yang dihitung berdasarkan perbandingan realisasi penerimaan Pajak Bumi dan Bangunan Perdesaan dan Perkotaan dengan target Pajak Bumi dan Bangunan Perdesaan dan Perkotaan. Untuk menghitung efektivitas maka menggunakan rumus sebagai berikut :

$$
\text { Efektifitas }=\frac{\text { Realisasi PBB-P2 }}{\text { Target PBB-P2 }} \times 100 \%
$$

\subsection{Kontribusi}

Kontribusi dalam pajak daerah adalah sejauh mana porsi atau hasil/jumlah dana yang terkumpul dari sektor pajak di suatu daerah dibandingkan dengan jumlah total pendapatan 
daerah. Kontribusi dalam PBB-P2 adalah suatu nilai untuk mengetahui tingkat kontribusi yang dihitung berdasarkan persentase perbandingan realisasi penerimaan Pajak Bumi dan Bangunan Perdesaan dan Perkotaan dengan realisasi Pendapatan Asli Daerah (PAD). Untuk menghitung kontribusi maka menggunakan rumus sebagai berikut :

$$
\text { Kontribusi PBB-P2 }=\frac{\text { Realisasi PBB-P2 }}{\text { Realisasi Pendapatan Asli Daerah }} \times 100 \%
$$

\subsection{Penelitian Terdahulu}

Subekti (2013) mengenai Evaluasi pelaksanaan pengalihan Pajak Bumi dan Bangunan Perdesaan dan Perkotaan (PBB-P2) di Surakarta. Hasil dari penelitian Hasil penelitian menunjukkan bahwa jadwal kegiatan peralihan pajak bumi dan bangunan tidak berjalan dengan lancar, karena adanya kegiatan yang tidak tepat waktu dari yang seharusnya telah dijadwalkan dilakukan oleh pihak terkait. Ida Ayu Metha Apsari Prathiwi (2015) mengenai Analisis Strategi Penerimaan Pajak Bumi dan Bangunan Pedesaan dan Perkotaan (PBB-P2) Serta Efektivitas Penerimaannya di Pemerintah Kota Denpasar Tahun 2013-2014. Hasil dari penelitian Kendala yang dialami oleh pemerintah Kota Denpasar adalah karena PBB-P2 merupakan pajak baru sehingga Pemda mengalami kesulitan dalam pengelolaannya, aplikasi SISMIOP yang diberikan oleh Direktorat Jenderal Pajak tidak berjalan dengan baik, sarana dan prasarana yang kurang memadai serta membutuhkan biaya yang besar, serta sumber daya manusia yang tidak optimal dalam memberikan pelayanan.

\section{METODE PENELITIAN}

\subsection{Jenis Penelitian}

Jenis penelitian yang digunakan adalah penelitian deskriptif. Penelitian deskriptif diartikan sebagai suatu penelitian yang berusaha mendeskripsikan suatu fenomena atau peristiwa secara sistematis sesuai dengan apa adanya. Penelitian deskriptif dilakukan untuk memperoleh informasi mengenai keadaan saat ini. Dalam penelitian deskriptif, peneliti mencoba menentukan sifat situasi sebagaimana adanya pada waktu penelitian dilakukan (Dantes, 2012: 51). Penelitian ini menganalisis efektivitas dan kontribusi Pajak Bumi dan Bangunan Perdesaan dan Perkotaan sebagai sumber Pendapatan Asli Daerah Kabupaten Minahasa, Kabupaten Minahasa Utara dan Kota Manado.

\subsection{Tempat dan Waktu Penelitian}

Penelitian dilaksanakan di Kantor Badan Pengelola Pajak dan Retribusi Daerah Kabupaten Minahasa, Kantor Badan Keuangan Minahasa Utara, dan Kantor Badan Pengelola Pajak dan Retribusi Daerah Kota Manado. Periode waktu penelitian dimulai pada Bulan Juni 2017.

\subsection{Metode Pengumpulan Data}

Metode pengumpulan data dalam suatu penelitian merupakan faktor yang cukup penting dalam mempengaruhi hasil penelitian. Pemilihan metode yang tepat akan diperoleh data yang tepat, relevan, dan akurat sehingga tujuan penelitian dapat tercapai. Penelitian ini menggunakan metode pengumpulan data sebagai berikut.

\subsubsection{Jenis Data}

Data adalah kumpulan informasi yang diperoleh dari suatu pengamatan, dapat berupa angka, lambang atau sifat. Jenis data menurut sifatnya terbagi 2 (dua) yaitu data kualitatif dan data kuantitatif.

1. Data kuantitatif adalah data yang berupa bilangan, nilainya bisa berubah-ubah atau bersifat variatif. Dalam penelitian ini data kuantitatif yang digunakan berupa jumlah penerimaan PBB-P2 dan jumlah penerimaan PAD tahun 2014-2016. 
2. Data kualitatif adalah data yang disajikan secara deskriptif atau dalam bentuk uraian yaitu target dan realisasi PBB-P2 serta target dan realisasi PAD di Kabupaten Minahasa, Kabupaten Minahasa Utara, dan Kota Manado.

\subsubsection{Sumber Data}

Sumber data dibedakan atas dua jenis, yaitu :

1. Data Primer

Data primer yang digunakan penulis merupakan hasil wawancara berupa tanya jawab langsung dengan pihak-pihak terkait. Dalam penelitian ini data primer yang digunakan adalah target dan realisasi PBB-P2 serta target dan realisasi PAD Kabupaten Minahasa, Kabupaten Minahasa Utara, dan Kota Manado.

2. Data Sekunder

Dalam penelitian ini data sekunder yang digunakan adalah peraturan daerah mengenai Pajak Bumi dan Banguan Perdesaan dan Perkotaan Kabupaten Minahasa, Kabupaten Minahasa Utara, dan Kota Manado..

\subsection{Teknik Pengumpulan Data}

Teknik pengumpulan data dalam penelitian ini yaitu:

1. Penelitian Kepustakaan (library research)

Penelitian kepustakaan adalah penelitian yang dilakukan dengan mengambil data dengan membaca buku-buku yang berkaitan dengan permasalahan yang akan diteliti.

2. Penelitian Lapangan

Penelitian lapangan adalah penelitian yang dilakukan terhadap kegiatan dari seluruh objek penelitian yaitu:

a. Wawancara

Wawancara yaitu tanya jawab langsung kepada responden untuk mendapatkan informasi. Wawancara dalam penelitian ini dilakukan dengan melakukan dialog bersama dengan staf bagian pajak dan bagian Keuangan untuk memperoleh informasi yang jelas tentang Pajak Bumi dan Bangunan Perdesaan dan Perkotaan dan Pendapatan Asli Daerah Kabupaten Minahasa, Kabupaten Minahasa Utara, dan Kota Manado.

b. Dokumentasi

Dokumentasi yaitu mengumpulkan bahan-bahan tertulis berupa data yang diperoleh dari perpustakaan maupun dari Kantor Badan Pengelola Pajak dan Retribusi Daerah Kabupaten Minahasa, Badan Keuangan Kabupaten Minahasa Utara, dan Badan Pengelola Keuangan dan Retribsi Daerah Kota Manado.

\subsection{Metode Analisis}

Metode analisis yang digunakan untuk membahas permasalahan dalam penelitian ini adalah metode analisis deskriptif kualitatif yaitu dengan cara menggambarkan kenyataan atau keadaan atas suatu objek dalam bentuk uraian kalimat berdasarkan keterangan-keterangan dari pihak-pihak yang berhubungan langsung dengan penelitian ini. Adapun tahapan analisis data yang digunakan dalam penelitian ini adalah sebagai berikut.

\subsubsection{Analisis Efektivitas}

$$
\text { Efektifitas }=\frac{\text { Realisasi PBB-P2 }}{\text { Target PBB-P2 }} \times 100 \%
$$

Untuk mengukur efektivitas, maka digunakan indikator sebagai berikut. 
Tabel 1. Klasifikasi Pengukuran Efektivitas

\begin{tabular}{|c|c|}
\hline Persentase & Kriteria \\
\hline$>100 \%$ & Sangat efektif \\
\hline $90-100 \%$ & Efektif \\
\hline $80-90 \%$ & Cukup efektif \\
\hline $60-80 \%$ & Kurang efektif \\
\hline$<60 \%$ & Tidak efektif \\
\hline
\end{tabular}

(Sumber: Depdagri, Kepmendagri No.690.900.327 (Rima Adelina, 2012)

3.5.2. Analisis Kontribusi

$$
\text { Kontribusi PBB-P2 }=\frac{\text { Realisasi PBB-P2 }}{\text { Realisasi Pendapatan Asli Daerah }} \times 100 \%
$$

Untuk mengukur kontribusi, maka digunakan indikator sebagai berikut.

Tabel 2. Klasifikasi Kriteria Kontribusi

\begin{tabular}{|c|c|}
\hline Persentase & Kriteria \\
\hline $0,00 \%-10 \%$ & Sangat kurang \\
\hline $10,10 \%-20 \%$ & Kurang \\
\hline $20,10 \%-30 \%$ & Sedang \\
\hline $30,10 \%-40 \%$ & Cukup baik \\
\hline $40,10 \%-50 \%$ & Baik \\
\hline Diatas $50 \%$ & Sangat baik \\
\hline
\end{tabular}

(Sumber: Depdagri, Kepmendagri No.690.900.327 (Rima Adelina, 2012)

\section{HASIL PENELITIAN DAN PEMBAHASAN}

4.1. Pendapatan Asli Daerah (PAD) Kabupaten Minahasa, Kabupaten Minahasa Utara, dan Kota Manado

Tabel 3. Pendapatan Asli Daerah Kabupaten Minahasa Tahun 2014-2016

\begin{tabular}{|l|l|l|l|}
\hline Tahun & $\begin{array}{l}\text { Target PAD } \\
(\mathbf{R p})\end{array}$ & $\begin{array}{l}\text { Realisasi PAD } \\
(\mathbf{R p})\end{array}$ & $\begin{array}{l}\text { Persentase } \\
(\boldsymbol{\%})\end{array}$ \\
\hline 2014 & $61.922 .781 .924,00$ & $58.778 .368 .154,00$ & $94,92 \%$ \\
\hline 2015 & $75.084 .091 .894,00$ & $73.125 .539 .559,00$ & $97,39 \%$ \\
\hline 2016 & $78.352 .009 .650,00$ & $77.933 .004 .819,00$ & $99,46 \%$ \\
\hline
\end{tabular}

(Sumber : Data Badan Pengelola Keuangan dan Aset Daerah Kabupaten Minahasa)

Data pada tabel 3. realisasi PAD tahun 2014 sebesar Rp58.778.368.154,00 dan target PAD sebesar Rp61.922.781.924,00. Hal ini menunjukkan realisasi PAD hanya sebesar 94,92\%. Dari tahun 2014. Di tahun 2015 realisasi PAD Kabupaten Minahasa sebesar Rp73.125.539.559,00 dan target PAD sebesar Rp75.084.091.89,00. Hal ini menunjukkan bahwa realisasi PAD sebesar 97,39\% dari target tahun 2015. Pada tahun 2016 realisasi PAD sebesar Rp77.933.004.819,00 dan target PAD sebesar Rp78.352.009.650,00. Hal ini menunjukkan bahwa realisasi PAD sebesar 99,46\% dari target tahun 2016.

Tabel 4. Pendapatan Asli Daerah Kabupaten Minahasa Utara Tahun 2014-2016

\begin{tabular}{|l|l|l|l|}
\hline Tahun & $\begin{array}{l}\text { Target PAD } \\
(\mathbf{R p})\end{array}$ & $\begin{array}{l}\text { Realisasi PAD } \\
(\mathbf{R p})\end{array}$ & $\begin{array}{l}\text { Persentase } \\
(\boldsymbol{\%})\end{array}$ \\
\hline 2014 & $18.025 .000 .000,00$ & $20.070 .096 .061,00$ & $111,35 \%$ \\
\hline 2015 & $22.925 .000 .000,00$ & $25.266 .469 .042,00$ & $110,21 \%$ \\
\hline 2016 & $25.867 .500 .000,00$ & $30.072 .989 .664,00$ & $116,26 \%$ \\
\hline
\end{tabular}

(Sumber : Data Badan Keuangan Kabupaten Minahasa Utara) 
Data pada tabel 4. dapat dilihat bahwa relisasi PAD tahun 2014 sebesar Rp20.070.096.061,00 dan target PAD sebesar Rp18.025.000.000,00. Hal ini menunjukkan bahwa realisasi PAD sebesar 111,35\% dari target tahun 2014. Realisasi PAD tahun 2015 sebesar Rp25.266.469.042,00 dan target PAD sebesar Rp22.925.000.000,00. Hal ini menunjukkan realisasi PAD sebesar 110,21\% dari target tahun 2015. Realisasi PAD tahun 2016 sebesar Rp30.072.989.664,00 dan target PAD sebesar Rp25.867.500.000,00. Hal ini menunjukkan realisasi PAD sebesar116,26\% dari target tahun 2016.

Tabel 5. Pendapatan Asli Daerah Kota Manado Tahun 2014-2016

\begin{tabular}{|l|l|l|l|}
\hline Tahun & $\begin{array}{l}\text { Target PAD } \\
(\mathbf{R p})\end{array}$ & $\begin{array}{l}\text { Realisasi PAD } \\
(\mathbf{R p})\end{array}$ & $\begin{array}{l}\text { Persentase } \\
(\boldsymbol{\%})\end{array}$ \\
\hline 2014 & $257.771 .320 .560,00$ & $263.392 .296 .958,00$ & $102,18 \%$ \\
\hline 2015 & $273.391 .133 .000,00$ & $289.462 .741 .463,00$ & $105,87 \%$ \\
\hline 2016 & $288.228 .847 .854,00$ & $306.453 .382 .648,00$ & $106,32 \%$ \\
\hline
\end{tabular}

(Sumber: Data Badan Pengelola Pajak dan Retribusi Daerah Kota Manado)

Data pada tabel 5. menunjukkan bahwa realisasi PAD tahun 2014 sebesar Rp263.392.296.958,00 dan target PAD sebesar Rp257.771.320.560,00. Hal ini menunjukkan realisasi PAD sebesar 102,18\% dari target tahun 2014. Realisasi PAD tahun 2015 sebesar Rp289.462.741.463,00 dan target PAD sebesar Rp273.391.133.000,00. Hal ini menunjukkan realisasi PAD hanya sebesar 105,87\% dari target tahun 2015. Realisasi PAD tahun 2016 sebesar Rp306.453.382.648,00 dan target PAD sebesar Rp288.228.847.854,00. Hal ini menunjukkan realisasi PAD sebesar 106,32\% dari target tahun 2016.

\subsection{Efefktivitas PBB-P2 Kabupaten Minahasa, Kabupaten Minahasa Utara, dan Kota Manado}

Tabel 6. Efektivitas Penerimaan PBB-P2 Kabupaten Minahasa Tahun 2014-2016

\begin{tabular}{|c|c|c|c|c|}
\hline Tahun & $\begin{array}{c}\text { Target } \\
(\mathbf{R p})\end{array}$ & $\begin{array}{c}\text { Realisasi } \\
\text { (Rp) }\end{array}$ & $\begin{array}{c}\text { Persentase } \\
(\%)\end{array}$ & Kriteria \\
\hline 2014 & $5.039 .389 .723,00$ & $3.623 .829 .237,00$ & $71,91 \%$ & Kurang efektif \\
\hline 2015 & $5.085 .074 .397,00$ & $3.904 .629 .782,00$ & $76,78 \%$ & Kurang efektif \\
\hline 2016 & $5.660 .616 .405,00$ & $3.433 .445 .561,00$ & $60,65 \%$ & Kurang efektif \\
\hline \multicolumn{3}{|c|}{ Rata-rata } & $69,78 \%$ & Kurang efektif \\
\hline
\end{tabular}

(Sumber: Data Badan Pengelola Pajak dan Retribusi Daerah Kabupaten Minahasa)

Data tabel 6. menunjukkan tingkat efektivitas PBB-P2 paling tinggi pada tahun 2015 dengan persentase sebesar 76,78\%. Dibandingkan dengan tahun sebelumnya, yaitu tahun 2014 dengan jumlah persentase sebesar $71,91 \%$, sedangkan tingkat efektivitas paling rendah pada tahun 2016 dengan jumlah persentase sebesar 60,65\%. Tabel 6. menunjukkan penerimaan pajak bumi dan bangunan perdesaan dan perkotaan Kabupaten Minahasa rata-rata pada tahun 2014-2016 sebesar 69,78\%. Jika berdasarkan pada kriteria atau indikator tersebut maka penilaiannya kurang efektif.

Tabel 7. Efektivitas Penerimaan PBB-P2 Kabupaten Minahasa Utara Tahun 2014-2016

\begin{tabular}{|c|c|c|c|c|}
\hline Tahun & $\begin{array}{c}\text { Target } \\
\text { (Rp) }\end{array}$ & $\begin{array}{l}\text { Realisasi } \\
\text { (Rp) }\end{array}$ & $\begin{array}{c}\text { Persentase } \\
(\%)\end{array}$ & Kriteria \\
\hline 2014 & $3.000 .000 .000,00$ & $3.488 .511 .406,00$ & $116,28 \%$ & Sangat efektif \\
\hline 2015 & $4.850 .000 .000,00$ & $4.891 .422 .972,00$ & $100,85 \%$ & Sangat efektif \\
\hline 2016 & $4.900 .000 .000,00$ & $4.540 .469 .931,00$ & $92,66 \%$ & Efektif \\
\hline \multicolumn{3}{|c|}{ Rata-rata } & $103,26 \%$ & Sangat efektif \\
\hline
\end{tabular}

(Sumber: Data Badan Keuangan Kabupaten Minahasa Utara)

Data tabel 7. menunjukkan bahwa tingkat efektivitas PBB-P2 paling tinggi adalah pada tahun 2014 dengan persentase sebesar 116,28\%. Pada tahun 2015 tingkat efektivitas PBB-P2 sebesar 100,85\%, sedangkan tingkat efektivitas paling rendah pada tahun 2016 dengan 
persentase sebesar 92,66\%. Tabel 7. menunjukkan pajak bumi dan bangunan perdesan dan perkotaan Kabupaten Minahasa Utara rata-rata pada tahun 2014-2016 adalah sebesar $103,26 \%$. Jika berdasarkan pada kriteria atau indikator tersebut maka penilaiannya sangat efektif.

Tabel 8. Efektivitas Penerimaan PBB-P2 Kota Manado Tahun 2014-2016

\begin{tabular}{|c|c|c|c|c|}
\hline Tahun & $\begin{array}{c}\text { Target } \\
\text { (Rp) }\end{array}$ & $\begin{array}{l}\text { Realisasi } \\
\text { (Rp) }\end{array}$ & $\begin{array}{c}\text { Persentase } \\
(\%)\end{array}$ & Kriteria \\
\hline 2014 & $31.210 .524 .776,00$ & $28.740 .333 .816,00$ & $92,08 \%$ & Efektif \\
\hline 2015 & $30.000 .000 .000,00$ & $24.467 .264 .925,00$ & $81,55 \%$ & Cukup efektif \\
\hline 2016 & $24.534 .660 .000,00$ & $27.710 .018 .490,00$ & $112,94 \%$ & Sangat efektif \\
\hline \multicolumn{3}{|c|}{ Rata-rata } & $95,52 \%$ & Efektif \\
\hline
\end{tabular}

(Sumber: Data Badan Pengelola Pajak dan Retribusi Daerah Kota Manado)

Pada tabel 8. menunjukkan bahwa tingkat efektivitas PBB-P2 paling tinggi pada tahun 2016 dengan persentase sebesar 112,94\%. Tingkat efektivitas pada tahun 2014 dengan persentase sebesar 92,08\%, sedangkan tingkat efektivitas paling rendah ditunjukkan pada tahun 2015 dengan persentase sebesar $81,55 \%$. Tabel 8. menunjukkan bahwa pajak bumi dan bangunan perdesaan dan perkotaan Kota Manado rata-rata pada tahun 2014-2016 adalah sebesar $95,52 \%$. Jika berdasarkan pada kriteria atau indikator tersebut, maka penilaiannya efektif.

\subsection{Kontribusi PBB-P2 Terhadap PAD Kabupaten Minahasa, Kabupaten Minahasa Utara, dan Kota Manado}

Tabel 9. Kontribusi Pajak Bumi dan Bangunan Perdesaan dan Perkotaan PBB-P2 terhadap Pendapatan Asli Daerah (PAD) Kabupaten Minahasa Tahun 2014-2016

\begin{tabular}{|c|c|c|c|c|}
\hline Tahun & $\begin{array}{l}\text { Realisasi PBB-P2 } \\
\text { (Rp) }\end{array}$ & $\begin{array}{l}\text { Realisasi PAD } \\
\text { (Rp) }\end{array}$ & $\begin{array}{c}\text { Persentase } \\
(\%)\end{array}$ & Kriteria \\
\hline 2014 & $3.623 .829 .237,00$ & $58.778 .368 .154,00$ & $6,16 \%$ & Sangat kurang \\
\hline 2015 & $3.904 .629 .782,00$ & 73.125.539.559,00 & $5,33 \%$ & Sangat kurang \\
\hline 2016 & $3.433 .445 .561,00$ & $77.933 .004 .819,00$ & $4,40 \%$ & Sangat kurang \\
\hline \multicolumn{3}{|c|}{ Rata-rata } & $5,29 \%$ & Sangat kurang \\
\hline
\end{tabular}

(Sumber: Data Badan Pengelola Pajak dan Retribusi Daerah Kabupaten Minahasa)

Data tabel 9. menunjukkan bahwa kontribusi Pajak Bumi dan Bangunan Perdesaan dan Perkotaan terhadap pendapatan asli daerah Kabupaten Minahasa rata-rata dari tahun 2014 sampai dengan tahun 2016 adalah sebesar 5,29\%, jika berdasarkan kriteria indikator penilaian adalah sangat kurang

Tabel 10. Kontribusi Pajak Bumi dan Bangunan Perdesaan dan Perkotaan PBB-P2 terhadap Pendapatan Asli Daerah (PAD) Kabupaten Minahasa Utara Tahun 2014-2016

\begin{tabular}{|c|c|c|c|c|}
\hline Tahun & $\begin{array}{c}\text { Realisasi PBB-P2 } \\
\text { (Rp) }\end{array}$ & $\begin{array}{c}\text { Realisasi PAD } \\
\text { (Rp) }\end{array}$ & $\begin{array}{c}\text { Persentase } \\
(\%)\end{array}$ & Kriteria \\
\hline 2014 & $3.488 .511 .406,00$ & $20.070 .096 .061,00$ & $17,38 \%$ & Kurang \\
\hline 2015 & $4.891 .422 .972,00$ & $25.266 .469 .042,00$ & $19,35 \%$ & Kurang \\
\hline 2016 & $4.540 .469 .931,00$ & $30.072 .989 .664,00$ & $15,09 \%$ & Kurang \\
\hline \multicolumn{3}{|c|}{ Rata-rata } & $17,27 \%$ & Kurang \\
\hline
\end{tabular}

(Sumber: Data Badan Keuangan Kabupaten Minahasa Utara)

Berdasarkan tabel 10. menunjukkan bahwa kontribusi Pajak Bumi dan Bangunan Perdesaan dan Perkotaan terhadap Pendapatan Asli Daerah (PAD) Kabupaten Minahasa Utara rata-rata dari tahun 2014 sampai dengan tahun 2016 adalah sebesar 17,27\%, jika berdasarkan kriteria atau indikator yang ditetapkan maka penilaiannya adalah kurang. 
Tabel 11. Kontribusi Pajak Bumi dan Bangunan Perdesaan dan Perkotaan PBB-P2 terhadap Pendapatan Asli Daerah (PAD) Kota Manado Tahun 2014-2016

\begin{tabular}{|c|c|c|c|c|}
\hline Tahun & $\begin{array}{c}\text { Realisasi PBB-P2 } \\
\text { (Rp) }\end{array}$ & $\begin{array}{l}\text { Realisasi PAD } \\
\text { (Rp) }\end{array}$ & $\begin{array}{c}\text { Persentase } \\
(\%)\end{array}$ & Kriteria \\
\hline 2014 & $28.740 .333 .816,00$ & $263.392 .296 .958,00$ & $10,91 \%$ & Kurang \\
\hline 2015 & $24.467 .264 .925,00$ & $289.462 .741 .463,00$ & $8,45 \%$ & Sangat kurang \\
\hline 2016 & $27.710 .018 .490,00$ & $306.453 .382 .648,00$ & $9,04 \%$ & Sangat kurang \\
\hline \multicolumn{3}{|c|}{ Rata-rata } & $9,46 \%$ & Sangat kurang \\
\hline
\end{tabular}

(Sumber: Data Badan Pengelola Pajak dan Retribusi Daerah Kota Manado)

Data tabel 11. menunjukkan bahwa kontribusi Pajak Bumi dan Bangunan Perdesaan dan Perkotaan terhadap Pendapatan Asli Daerah (PAD) Kota Manado rata-rata dari tahun 2014 sampai dengan tahun 2016 adalah sebesar 9,46\%, jika berdasarkan kriteria atau indikator yang ditetapkan maka penilaiannya adalah sangat kurang.

\subsection{Pembahasan}

Efektivitas Pajak Bumi dan Bangunan Perdesaan dan Perkotaan menunjukkan bahwa Kabupaten Minahasa Utara sebesar 103,26\% (sangat efektif lebih tinggi dibandingkan Kota Manado sebesar 95,52\% (efektif) dan Kabupaten Minahasa sebesar 69,78\% (kurang efektif). Ini menunjukkan bahwa Kabupaten Minahasa Utara dalam efektivitas PBB-P2 selama tiga tahun terakhir lebih baik.

Pada tahun 2014 Kabupaten Minahasa Utara saat adanya pengalihan PBB-P2 menjadi Pajak Daerah menunjukkan bahwa realisasi Pajak Bumi dan Bangunan Perdesaan dan Perkotaan jauh di atas target yang ditentukan, dimana dalam tahun 2014 sampai dengan tahun 2015 tingkat keefektifannya digolongkan sangat efektif. Hal ini disebabkan adanya sosialisasi dan pembinaan secara langsung maupun media massa kepada masyarakat. Pada tahun 2016 tingkat keefektifannya digolongkan efektif, karena sebagian besar masyarakat atau wajib pajak membayar kewajiban pajaknya.

Pemerintah Kota Manado rata-rata tingkat keefektifannya dapat digolongkan efektif dari tahun ke tahun sejak dilimpahkan kewenangan PBB-P2 dari pajak pusat menjadi pajak daerah, dapat dilihat realisasi PBB-P2 jauh dari target yang ditetapkan dari tahun 2014 sampai dengan tahun 2016. Pemerintah Kabupaten Minahasa rata-rata keefektifannya digolongkan kurang efektif. Realisasi PBB-P2 jauh dibawah dari target yang ditetapkan pada tahun 2014 sampai dengan tahun 2016 dan tidak mengalami peningkatan. Hal ini disebabkan karena realisasi penyetoran Pajak Bumi dan Bangunan Perdesaan dan Perkotaan (PBB-P2) di Kabupaten Minahasa masih minim.

Kontribusi dalam penerimaan Pajak Bumi dan Bangunan Perdesaan dan Perkotaan terhadap Pendapatan Asli Daerah menunjukkan bahwa Minahasa paling rendah dengan persentase sebesar 5,29\% (sangat kurang), Kota Manado sebesar 9,46\% (sangat kurang), sedangkan Kabupaten Minahasa Utara paling tinggi dengan persentase sebesar 17,27\% (kurang). Hal ini menunjukkan bahwa Kabupaten Minahasa, Kabupaten Minahasa Utara, dan Kota Manado belum maksimal dalam pengelolaan PBB-P2, kurangnya pemanfaatan dan mengoptimalkan penerimaan yang tergolong dalam objek pajak PBB-P2 serta adanya faktor lain yang mempengaruhi kurangnya kontribusi PBB-P2 dalam Pendapatan Asli Daerah.

Pemerintah Kabupaten Minahasa, Kabupaten Minahasa Utara, dan Kota Manado harusnya lebih mengoptimalkan pemungutan terhadap PBB-P2, sehingga dapat memberikan kontribusi yang lebih meningkat ditahun selanjutnya. Dengan adanya kerjasama dengan pihak-pihak yang terkait dalam pelaksanaan pemungutan, dan pengelolaan PBB-P2. Seperti adanya objek tapi tidak adanya penetapan tarif pajak, maupun sebaliknya adanya penetapan pajak tapi tidak memiliki objek. Banyaknya data yang tidak akurat dan tidak sesuai dengan 
kondisi lapangan yang sebenarnya sehingga penerimaan yang kurang optimal. Selain itu, kurangnya kesadaran wajib pajak dalam membayar PBB-P2 juga menjadi faktor penghambat untuk meningkatkan penerimaan PBB-P2.

\section{KESIMPULAN DAN SARAN}

\subsection{Kesimpulan}

Berdasarkan hasil penelitian dan pembahasan pada bab sebelumnya, maka kesimpulannya, antara lain:

1. Efektivitas Pajak Bumi dan Bangunan Perdesaan dan Perkotaan yang digambarkan dalam hasil penelitian Kabupaten Minahasa Utara 103,26\% (sangat efektif) lebih tinggi dibandingkan Kota Manado 95,52\% (efektif) dan Kabupaten Minahasa hanya sebesar $69,78 \%$ (kurang efektif). Hasil penelitian ini menunjukkan bahwa Kabupaten Minahasa Utara mengalami peningkatan atau pertumbuhan yang lebih baik.

2. Kontribusi dalam penerimaan Pajak Bumi dan Bangunan Perdesaan dan Perkotaan terhadap Pendapatan Asli Daerah (PAD) Kabupaten Minahasa 5,29\% (sangat kurang), dan Kabupaten Minahasa Utara 17,27\% (kurang) lebih tinggi dibandingkan Kota Manado 9,46\% (sangat kurang). Hasil penelitian tersebut menunjukkan bahwa pemerintah Kabupaten Minahasa, Kabupaten Minahasa Utara dan Kota Manado kurang optimal dalam pengelolaan PBB-P2 sebagai sumber pendapatan bagi daerahnya masing-masing.

\subsection{Saran}

1. Untuk Pemerintah Kabupaten Minahasa Utara sebaiknya harus mengekstensifikasi PBB-P2, mencari potensi baru di bidang PBB-P2

2. Untuk pemerintah Kota Manado sebaiknya mengektensifikasi potensi baru di bidang PBB-P2. Upaya ekstensifikasi pajak dapat dilakukan dengan cara memperluas wajib pajak, penyempurnaan tarif, dan perluasan objek pajak.

3. Untuk Pemerintah Kabupaten Minahasa sebaiknya melakukan upaya penyempurnaan administrasi pajak, dan peningkatan mutu pegawai atau petugas pemungut. dengan memperkuat sistem informasi baik dari kelurahan dan kecamatan itu sendiri, melakukan pendataan ulang.

4. Untuk pemerintah Kabupaten Minahasa, pemerintah Kabupaten Minahasa Utara, dan pemerintah kabupaten Kota Manado agar mensosialisasikan kepada masyarakat batas akhir pembayaran pajak PBB-P2 tanggal 30 September.

\section{DAFTAR PUSTAKA}

Adelina, Rima, 2012. Analisis Efektivitas dan Kontribusi Penerimaan Pajak Bumi dan Bangunan (PBB) Terhadap Pendapatan Daerah di Kabupaten Gresik. Skripsi. Universitas Negeri Surabaya. Surabaya.

Agoes, Sukrisno. Trisnawati, Estralita. 2013. Akuntansi Perpajakan. Edisi-3. Salemba Empat.Jakarta.

Aji, Mohamad Nur Istiyanto, 2014. Analisis Pajak Bumi dan Bangunan Perkotaan di Kota Semarang Tahun 2012-2013. Skripsi. Fakultas Ilmu Sosial dan Ilmu Politik. Universitas Diponegoro Semarang. Semarang.

Dantes, Nyoman. 2012. Metode Penelitian. Andi. Yogyakarta.

Kementerian Keuangan Republik Indonesia. Direktorat Jenderal Perimbangan Keuangan.

2014. Pedoman Umum Pengelolaan PBB-P2. Jakarta..

Hery. 2012. Akuntansi Keuangan Menengah I. PT Bumi Aksara. Jakarta

Hery. 2017. Akuntansi Dasar 1\&2. Grasindo. Jakarta.

Lubis, Irsan. 2015. Mahir Akuntansi Pajak Terapan. Andi. Yogyakarta. 
Mardiasmo, 2016. Perpajakan. Edisi Revisi. Andi. Yogyakarta.

Pemerintah Republik Indonesia. 2009. Undang-Undang Nomor 28 Tahun 2009. Tentang Pajak Daerah dan Retribusi Daerah.

Pemerintah Republik Indonesia. 2012. Peraturan Daerah Kota Manado Nomor 07 Tahun 2012 Tentang Pajak Bumi dan Bangunan.

Pemerintah Republik Indonesia. 2013. Peraturan Daerah Kabupaten Minahasa Nomor 1 Tahun 2013 Tentang Pajak Bumi dan Bangunan Perdesaan dan Perkotaan Kabupaten Minahasa.

Pemerintah Republik Indonesia. 2009. Undang-Undang Nomor 16 Tahun 2009. Tentang Ketentuan Umum dan Tata Cara Perpajakan.

Pemerintah Republik Indonesia. 2004. Undang-Undang Nomor 33 Tahun 2004. Tentang Perimbangan Keuangan Pusat dan Daerah.

Prathiwi, Ida Ayu Metha Apsari, 2015. Analisis Strategi Penerimaan Pajak Bumi dan Bangunan Pedesaan dan Perkotaan (PBB-P2) Serta Efektivitas Penerimaannya di Pemerintah Kota Denpasar Tahun 2013-2014. E-Journal S1 Ak. Universitas Pendidikan Ganesha Singaraja. Denpasar.

Priantara, Diaz. 2013. Perpajakan Indonesia. Edisi 2 Revisi. Mitra Wacana Media. Jakarta.

Resmi, Siti. 2016. Perpajakan Teori dan Kasus. Edisi 9. Buku 1. Salemba Empat. Jakarta

Sadeli, 2016. Dasar-Dasar Akuntansi. Bumi Aksara. Jakarta

Sari Diana, 2013. Konsep Dasar Perpajakan. Refika Aditama. Bandung.

Subekti, 2013. Evaluasi Pelaksanaan Pengalihan PBB-P2 Di Surakarta. Skripsi. Universitas Sebelas Maret. Surakarta.

Wulansepty, Dinar. 2014. Strategi Pemungutan PBB Kota Surabaya Terhadap Realisasi Target Penerimaan Tahun 2009-2012. Jurnal Ilmu dan Riset Akuntansi Vol. 3 No. 10. Sekolah Tinggi Ilmu Ekonomi Indonesia. Surabaya.

Samudra, A. A. 2015. Perpajakan di Indonesia. PT Raja Grafindo Persada. Jakarta.

Sumarsan, Thomas. 2015. Perpajakan Indonesia. Indeks. Jakarta Barat.

Waluyo. 2013. Perpajakan Indonesia. Edisi ke-11. Salemba Empat. Jakarta. 